\title{
Kampanye Politik di Media Online: Analisis Framing Pada Situs JPNN.com dan TribunJatim.com
}

\author{
Rahadi $^{1}$ \\ rhadi@umm.ac.id
}

\begin{abstract}
Post-reform, mass media plays an important role in political life in Indonesia. Media power in presenting or reporting political events in the form of news often has a significant impact on political developments in the country. This study focuses on political news on JPNN.com and TribunJatim.com, regarding the construction of the Governor of Deputy Governor and Deputy Governor of East Java in 2018. The researcher used Robert N Entman's framing analysis of four media analysis strategies; (1) Problem identification (2) diagnose causes (3) make moral judgment (4) treatment recommendations. The news frame carried out by JPNN.com and TribunJatim.com clearly uses the figure of Kiayi as a way to get sympathy from voters, especially those in the horseshoe and Madura region which incidentally is NU's mass base. For the East Java region outside the horseshoe and madura area (arek and matraman), the framing of the news carried out was that the candidate pairs received support from community organizations and emphasized the figure who was able to win over the problems in East Java.
\end{abstract}

Keywords: Framming analysis, JPNN.com, Media Ideology, TribunJatim.com

\begin{abstract}
Abstrak
Pasca reformasi, media massa memegang peranan penting dalam kehidupan politik di Indonesia. Kekuasaan media dalam menyajikan atau melaporkan peristiwa-peristiwa politik dalam bentuk berita sering memberi dampak signifikan bagi perkembangan politik di tanah air. Penelitian ini memokuskan pada berita politik di JPNN.com dan TribunJatim.com, tentang konstruksi berita Pemilihan Gubernur dan Wakil Gubernur Jawa Timur tahun 2018. Peneliti menggunakan analisis framing Robert N Entman yakni empat strategi analisis media; (1) Problem identification (2) diagnose causes (3) make moral judgement (4) treatment recommendations. Bingkai berita yang dilakukan oleh JPNN.com dan TribunJatim.com secara jelas menggunakan ketokohan Kiayi sebagai cara untuk mendapatkan simpati pemilih terutama yang berada di wilayah tapal kuda dan Madura yang notabene merupakan basis massa NU. Untuk wilayah jawa timur diluar wilayah tapal kuda dan madura (arek dan matraman), framing pemberitaan yang dilakukan adalah pasangan calon mendapatkan dukungan dari organisasi masyarakat serta menekankan pada sosok yang mampu mengurai permasalahan di Jawa Timur
\end{abstract}

Kata Kunci: Analisis framing, Ideologi Media, JPNN.Com, TribunJatim.com

\footnotetext{
${ }^{1}$ Korespondensi: Rahadi. Program Studi Ilmu Komunikasi UMM, Jl Raya Tlogomas 246 GKB 1 Lt6, 0341-464318 ext 135
} 


\section{Pendahuluan}

Pasca reformasi, media massa memegang peranan penting dalam kehidupan politik di Indonesia. Kekuasaan media dalam menyajikan atau melaporkan peristiwa-peristiwa politik dalam bentuk berita sering memberi dampak signifikan bagi perkembangan politik di tanah air. Fungsi Media massa tidak hanya sebagai sumber informasi (to inform), namun juga dapat menjadi pemicu perubahan politik (baik dari sisi ideologi negara maupun masyarakat). Mengingat kemampuan dan jumlah audience (pembaca) yang dipunyai oleh media massa bisa dikatakan besar, pasti akan berimbas pada pembentukan opini dan wacana pembaca melalui berita yang diwartakan.

Bukan menjadi sesuatu rahasia jika media yang seharusnya menjadi lembaga keempat (fourth estate) yang mengawal proses demokratisasi (di ranah lokal), justru media lokal banyak yang berubah fungsi menjadi kepanjangan pemimpin daerah, sehingga media lokal dalam tinjauan komunikasi politik lebih berperan sebagai agen politik daripada saluran komunikasi politik. Pada awalnya memang media massa merupakan komponen yang berfungsi untuk mengontrol kekuasaan pemerintah dalam suatu negara atau dalam istilah populernya fungsi watch dog. Seingga diharapkan bisa menjaga agar tidak terjadi abuse of power (Subiakto dan Ida, 2012: 122)

Dalam membuat liputan berita politik yang memiliki dimensi pembentukan opini publik, media massa umumnya melakukan tiga kegiatan sekaligus yang dipakai untuk mengkonstruksi realitas. Ibnu hamad dalam bukunya yang berjudul konstruksi realitas politik dalam media massa mengatakan pembentukan opini public olek media massa dapat melalui; pertama menggunakan simbol-simbol politik (langue of politic), kedua, melaksanakan strategi pengemasan pesan (framing strategies), ketiga, melakukan fungsi agenda setting media (agenda setting function) (Hamad, 2004: 2-3).

Dalam konstruksi pembuatan berita sangat dimungkinkan media juga melakukan manipulasi-manipulasi untuk mencapai apa yang diinginkannya, dengan demikian boleh jadi satu peristiwa politik bisa menimbulkan opini publik yang berbeda-beda tergantung dari cara masing-masing media mengkonstruksi berita politik 
Melihat realitas diatas, penelitian ini memfokuskan pada pembingkaian pemberitaan calon gubernur dan wakil gubernur oleh tribun jatim.com dan jpnn.com. pemili-han gubernur dan calon gubernur Jawa timur periode 2018-2023 saat ini diikuti oleh dua pasangan calon; calon nomor 1 adalah Saifullah Yusuf alias Gus Ipul yang berpasangan dengan Puti Guntur Soekarno, dan pasangan no 2 Khofifah Indar Parawansa berpasangan dengan Emil Elistanto Dardak.

\section{Tinjauan Pustaka}

\section{Komunikasi Politik Di Media}

Dalam melakukan kegiatan komunikasi politik tentu tidak terlepas dari saluran saluran atau media yang akan digunakan. Hal ini terkait dengan efekfititas kegiatan komunikasi yang dilakukan. Jadi seorang komunikator politik harus mengidentifikasikan basis massa yang akan menjadi target kegiatan politiknya tersebut dapat dijangkau dengan media apa. Apakah menggunakan cara konvensional (face to face) ataukah menggunakan media massa.

Dalam kegiatan komunikasi politik, fungsi media massa sebagai sumber informasi politik, fungsi partisipasi, fungsi sosialisasi dan pendidikan politik, fungsi mengembangkan budaya politik, fungsi integritas bangsa. Selain itu media juga berperan sebagai fungsi sosial, hiburan dan kontrol. Romli (2007:1-2) mengatakan media massa dalam melakukan fungsi sebagai sumber informasi selalu menyajikan, menayangkan peristiwa peristiwa politik yang terjadi di berbagai penjuru dunia, termasuk kegiatan aktor-aktor politik dengan sikap dan perilaku politik yang melekat pada para aktor tersebut. Sebagai fungsi sumber informasi lebih menitik beratkan kepada unsur-unsur berita (news) yang berefek pada kepentingan politik. Beberapa unsur-unsur yang harus dipenuhi dalam pemberitaan politik, yaitu: publisitas, aktualitas dan popularitas.

Fungsi kedua, yaitu fungsi partisipasi. Hal ini mengandung makna bahwa sajian atau tayangan pesan-pesan komunikasi baik pada media elektronik maupun media cetak harus mampu menggugah masyarakat (komunikan) untuk berperan aktif dalam mendukung dan melaksanakan berbagai kebijaksanaan pemerintah sebagai konsekuensi bahwa pemerintah adalah produk pilihan mereka. Fungsi ketiga, sosialisasi dan pendidikan politik. Fungsi ini untuk meningkatkan kesadaran 
masyarakat didalam menerima segala bentuk informasi. Memang fungsi sosialisasi dan pendidikan politik merupakan salah satu bentuk tanggung jawab dari adanya partaipolitik. Namun tidak dapat dipungkiri bahwa media massa juga mempunyai tanggung jawab atas sosialisasi dan pendidikan politik yang harus bebas dari kepentingan partai politik walaupun saat ini masih sulit untuk dilakukan mengingat para petinggi partai politik di Indonesia juga merupakan pemilik media.

Fungsi keempat, yaitu membangun politic culture (budaya politik). Budaya politik membentuk pola perilaku yang memberi warna dominan terhadap karakter masyarakat. Apakah mempunyai karakter tradisional atau rasional. Fungsi kelima, yaitu fungsi integritas bangsa. Fungsi ini merupakan syarat mutlak bagi kehidupan negara didalam mencapai tujuannya. Karena itu media massa harus mampu mengembangkan pemikiran-pemikiran yang menyatukan bangsa.

\section{Konstruksi Berita Kampanye di Media Massa: Teori dan Efek}

Roger dan Storey dalam Gun gun (2018:89) mengartikan kampanye adalah rangkaian tindakan komunikasi yang terencana dengan tujuan menciptakan efek yang telah direncanakan pada khalayak yang dilakukan secara simultan dalan rentang waktu tertentu. Bisa dikatakan juga kampanye adalah aktifitas komunikasi persuasif yang dirancang untuk mempengaruhi dan merubah perilaku serta tindakan khalayak. Jika dirunut berdasarkan waktu, kegiatan kampanye biasanya massif dilaksanakan dalam rentang waktu menjelang pesta demokrasi, sehingga dibutuhkan strategi yang tepat untuk aktifitas kampanye tersebut; salah satunya adalah menggunakan media massa.

Dalam aktifitas politik, kampanye merupakan kegiatan yang lazim dan wajib dilakukan oleh setiap orang yang ingin mendapatkan dan mempertahankan kekuasaan. Secara definisi kampanye adalah aktifitas komunikasi dalam rangka untuk meyakinkan/mempengaruhi/ mempersuasif massa dengan sengaja dengan strategi yang berkelanjutan pada periode tertentu. Nugroho (2009:67) menjelaskan bahwa dalam perhelatan pemilihan kepala daerah, pemberitaan media acapkali dipandang sebagai political message.

Pada prinsipnya, konstruksi realitas kampaye politik di media massa (cetak, elektronik dan televisi) merupakan usaha untuk membentuk dan 
mempersepsikan dengan cara menceritakan hal-hal yang berkaitan tentang kepentingan politik suatu golongan. Aktivitas media tak terlepas dari penyampaian realitas atau peristiwa yang sudah barang tentu akan dikonstruksikan sedemikian rupa oleh pengambil kebijakan di media (ini merupakan faktor internal media). Selain faktor internal juga terdapat faktor eksternal yang mempengaruhi konstruksi pemberitaan yaitu realitas pasar dan kenyataan politik.

Di era politik modern, saat ini media massa menjadi bagian dari politik praktis, sehingga keberadaannya sangat vital dalam percaturan politik. Bisa dikatakan saat ini media juga menjadi aktor atau pemain bukan sekedar penyampai pesan politik. Berita-berita yang diedarkan ke masyarakat tentunya sudah dikonstruksikan sedemikian rupa sesuai dengan kepentingan media tersebut. Misalnya saja penentuan peristiwa mana yang akan diberitakan, siapa tokohnya, dan persoalan (frame) apa yang berkenaan dengan peristiwa yang harus ditonjolkan (salience) serta seberapa sering peristiwa tersebut diberitakan. Disilah agenda setting yang dilakukan oleh media bekerja, karena apa yang dipandang penting oleh media begitu juga dengan yang dipandang oleh publik. Teori yang dipopulerkan oleh Newcomb dan Shaw ditahun 1972 ini berkesimpulan bahwa penonjolan isu yang dilakukan oleh media akan memengaruhi pandangan publik.

Eriyanto (2018:12) mengatakan bahwa teori agenda setting mempunyai dua konsep utama yakni (1) agenda media merujuk pada peristiwa yang akan diberitakan oleh media, misalnya penempatan berita dihalaman depan, penambahan foto yang menjadikan berita menjadi lebih menonjol dari berita yang lain. (2) agenda publik merujuk pada isu atau peristiwa yang ada dalam pikiran publik, artinya media melakukan survei isu apa yang menurut publik dianggap penting. Selanjutnya ketika berita dengan isu yang sudah ditonjolkan tersebut diberitakan secara terus-menerus pasti akan tersimpan dalam pikiran masyarakat.

Dalam perkembangannya teori agenda setting mengalami penyempurnaan atas asumsi yang dibangun. Pada teori agenda setting tahap pertama mendapatkan kritik karena hanya mengidentifikasikan dan mengategorisasikan isu dari berita, tanpa menyelidiki bagaimana orientasi berita dan apa dampak dari orientasi berita tersebut kepada publik. Selanjutnya muncul teori agenda agenda setting tahap kedua. Pada tahap kedua ini teori agenda setting media memokuskan 
pada atribut yang lebih rinci dari objek yang diberitakan. Misalnya merinci atribut kepribadian calon peserta pemilu seperti sosok yang dekat dengan rakyat, religious, tegas, mampu menyelesaikan permasalahan yang ada. Agenda setting tingkat pertama maupun tingkat kedua sama-sama memberikan penonjolan pada isu yang diberitakan perbedaannya adalah pada tahap pertama lebih menonjolkan objek sedangkan pada tahap kedua lebih menonjolkan pada atribut. Perkembangan selanjutnya adalah agenda setting tahap ketiga, yakni penggabungan antara agenda setting tahap pertama dan kedua (objek dan atribut saling berkorelasi).

Mudahnya akses informasi seiring dengan perkembangan teknologi komunikasi dan beralihnya kebiasaan masyarakat mengakses berita, dari media cetak ke media online memungkinkan berbagai macam isu yang diberitakan oleh media lebih cepat dikonsumsi oleh masyarakat. Tak bisa dipungkiri masyarakat saat ini lebih sering menggunakan media massa online sebagai sumber rujukan utama (terlepas apakah berita tersebut berasal dari media yang valid informasinya ataukah tidak) untuk selanjutnya berita tersebut akan dibagikan ke media sosial. Jika hal ini terjadi secara berulang kali dan masyarakat mengamini berita tersebut, maka bisa dipastikan media berhasil dalam mengarahkan pandangan masyarakat (priming) untuk menjadi opini publik

Willnat dan Zhu dalam Eriyanto (2018: 131) mengatakan, bahwa priming mempunyai dampak besar dalam pembentukan opini public. Priming muncul ketika media memberikan penekanan dan perhatian pada isu tertentu, sehingga muncul isu yang digunakan oleh public sebagai acuan. Sebagai contoh dalam pemilihan Gubernur dan Wakil Gubernur, dari hasil survei calon pemilih menunjukkan bahwa, calon pemilih cenderung memilih calon pemimpin yang mempunyai kemampuan menyelesaikan permasalahan kemiskinan, memiliki sikap dan tegas jujur, dan agamis maka pemberitaan di media akan menampilkan sosok tersebut pada kandidat tertentu sebagai cara atau strategi mengarahkan penilaian masyarakat kepada kandidat tersebut.

Menurut Laswell sebagaimana dikutip Pawito (2009:87-88), media massa mempunyai tiga fungsi pokok dalam dunia politik yaitu: (1) Fungsi pengawasan: merujuk pada aktifitas mencermati dan melaporkan peristiwa penting kepada public. (2) Fungsi Penghubung: sarana berdiskusi, bertukar pendapat, dan aspirasi bagi 
seluruh kelompok masyarakat. (3) Fungsi Transmisi warisan social: proses sosialisasi nilai, norma, dan kesepakan yang berkembang di masyarakat agar tercapai aturan social. Pendapat Laswell diatas memang merupakan sebuah idealisme dari media massa. Namun pada kenyataan, saat ini media massa tidak lagi sebuah lembaga yang murni dalam perjuangannya. Media menjadikan dirinya sebuah kelompok dominan yang menyebarkan pengaruhnya dengan meminggirkan kelompok yang lain.

Penggunaan media massa untuk kegiatan kampanye politik mempunyai pengaruh yang besar terhadap kepentingan para kandidat. Jangkauan yang luas, biaya yang relative lebih "murah" dibandingkan jika kandidat harus datang atau bertemu langsung dengan masyarakat. Walaupun sampai saat ini keberhasihan seorang kandidat tidak selalu berbanding lurus dengan adanya pemberitaan yang masif dari media, McQuail menjabarkan kampanye kemungkinan dapat berhasil jika; ada monopoli dari media massa yang digunakan. Artinya menguasai media arus utama dalam rangka menyampaikan pesan kampanye politik yang sama dan antar media tersebut saling melengkapi dan menguatkan (Subiakto, Ida. 2015:108-109). Pendapat Subiakto dan Ida tersebut dikuatkan oleh Rush dan Althoff yang menyatakan bahwa monopoli media oleh penguasa dengan menyampaikan pesan secara terus menerus dan dikuatkan dengan penggunaan media lainnya menjadi sarana yang efektis oleh penguasa kepada masyarakatnya (Rush dan Althoff. 2007:271).

\section{Level Pengaruh Isi Media}

Membangun image politik seorang calon yang akan berlaga pada pemilihan kepala daerah memang tidak dapat dikatakan mudah. Apalagi jika sang calon mempunyai tingkat popularitas dan elektabilitas rendah. Saat ini hampir setiap hari kita tak lepas dari smartphone. Mencari berita, membagikan berita, berkomunikasi dengan teman, berjualan secara online dan masih banyak lagi dapat kita lakukan dengan sangat mudah. Semua sudah berada ditangan kita. Namun disisi lain terkait dengan informasi yang bertebaran dimedia internet tak sedikit informasi atau berita yang tidak dapat dipertanggungjawabkan kebenarannya (HOAX). Menurut Ardian husaini yang dikutip oleh Kun Wasis dalam bukunya media massa dan kontruksi realitas (2012: 137) dalam kode etik jurnalistik PWI ada aturan yang melarang untuk mencampuradukkan antara fakta dan opini. Fakta harus disajikan 
sebagai fakta, dan begitu juga dengan opini harus disajikan sebagai opini. Sehingga keberimbangan atas berita yang disampaikan tetap terjaga.

Realitas yang dapat kita saksikan saat ini adalah begitu banyaknya penggiringan opini publik yang menjadi konten berita pada media massa untuk kepentingan kelompok tertentu. Apabila opini yang dibuat oleh media massa ini sudah terbentuk di masyarakat, maka akan muncul pemaknaan atas sesuatu yang bersifat general yang cenderung untuk menuduh, mengunggulkan kelompok tertentu.

Untuk mengurangi dampak dari munculnya konten-konten yang tidak bisa dipertanggung jawabkan isinya tersebut, ada bebrapa cara yang dapat dilakukan, antara lain; dengan membaca banyak sumber referensi lain atau referensi yang membahas tentang pemberitaan yang sama dari media-media laiinya. selanjutnya membangun pengetahuan tentang literasi media, dan yang terakhir pemahaman bahwa dalam memproduksi berita pasti ada benturan antara struktur (sumber daya) dan agensi (tindakan, entah itu dari jurnalis/editor/redaktur).

Melihat kenyataan atau realitas tentu menarik untuk dilihat lebih mendalam lagi hal-hal yang mempengaruhi atau bisa dikatakan mengintervensi media massa dalam memberitakan sebuah realitas. Menurut Pamela J. Shoemoker dan Stephen D. Reese beberapa faktor yang mempengaruhi pengambilan keputusn dalam pemberitaan realitas di media massa adalah sebagai berikut (Sudibyo, 2001:7): (1) Level individu: berhubungan dengan latar belakang pengelola media. Bisa dilihat dari aspek latar belakang pendidikan, jenis kelamin, agama, ideology. (2) Level rutinitas media: mekanisme dan proses penentuan berita yang akan diproduksi sampai pada tahap naik cetak. (3) Level organisasi: berhubungan dengan struktur organisasi yang secara hirarki pasti akan mempengaruhi pemberitaan. (4) Level ekstramedia: berhubungan dengan lingkungan diluar media missalnya sumber berita (narasumber), sumber penghasilan media, kebijakan pemerintah. (5) Level ideologi: kerangka berpikir atau referensi yang dipakai oleh individu untuk melihat realitas.

\section{Analisis Framming Robert N. Entman}

Menurut Eriyanto dalam Herayati, Wayan Wendra, Budi Utama (2016) Robert N Entman adalah seorang ahli yang meletakkan dasar-dasar bagi analisis framing untuk studi isi media. Bagi Entman teks merupakan representasi yang 
sengaja ditampilkan kepada masyarakat dengan penekanan isu yang dianggap penting oleh wartawan. Misalnya kecenderungan pemberitaan suatu media terhadap suatu isu apakah cenderung positif ataukah cenderung negatif. Hal ini tentu akan berakibat pada perbedaan pembaca terhadap suatu isu.

Entman membagi framing menjadi dua yakni seleksi isu dan penekanan aspek-tertentu dari realitas atau isu (Eriyanto, 2011:221). Penekanan isu isu tersebut bisa berupa judul berita, headline, grafis, pelebelan terhadap seseorang. Sehingga sangat memungkinkan seorang wartawan menentukan fakta apa yang diambil (ditonjolkan) dan fakta apa yang tidak diambil.

Perangkat analisis framing menurut entman dibagai menjadi empat; (1) Definisi masalah (define problem): bagaimana isu atau peristiwa dipahami oleh wartawan. Sangat memung-kinkan peristiwa yang sama dapat dipahami berbeda oleh wartawan. Ini diakibatkan karena pembingkaian suatu peristiwa juga didasarkan pada ideologi dan kepentingan media sebagai "rumah" dari wartawan. (2) Sumber masalah (diagnose causes): membingkai siapa tokoh yang akan dijadikan aktor dalam pemberitaan sebuah berita. (3) Membuat keputusan moral (make moral judgement): membenarkan atau memberi argumentasi pada realitas, dan (4) Menekankan penyelesaian (Treatment recommendation): penyelesaian isuatau masalah dari realitas yang sudah ditentukan.

Sobur dalam Anggoro (2014:30) menyatakan bahwa, penonjolan berita tersebut diatas merupakan proses menjadikan informasi menjadi lebih bermakna. Realitas yang disajikan mempunyai peluang yang besar untuk mempengaruhi khalayak.

\section{Metode Penelitian}

Dalam penelitian ini, peneliti menggunakan pendekatan kualititif. sehingga dapat menjelaskan realitas secara deskriptif dalam bentuk kalimat. Ruang lingkup penelitian ini adalah pemberitaan pada JPNN.com dan TribunJatim.com tanggal 1-10 April 2018. Data yang digunakan sebagai bahan penelitian adalah kalimat dalam berita yang mengandung konten tentang pemberitaan pasangan calon gubernur dan wakil gubernur Jawa Timur. Sehingga tidak semua berita yang dimuat di JPNN.com dan TribunJatim.com menjadi bahan penelitian 
Teknik pengumpulan data dilakukan dengan cara mendokumentasikan pemberitaan terkait pencalonan gubernur dan wakil gubernur Jawa Timur tahun 2018 dengan cara mengopy berita dari web. Selanjutnya metode analisis yang digunakan adalah analisis framing dari Model Robert N Entman.

\section{Hasil dan Pembahasan}

Dari hasil analis yang dilakukan pada kedua media; JPNN.com dan TribunJatim.com ditemukan dua kontruksi isu besar yang dilakukan, yakni berita tentang Legitimasi dukungan dari tokoh masyarakat dan tokoh agama (Kyai) dan legitimasi dari tokoh nasional dan organisasi masyarakat dan partai politik

Tabel 1. Analisis Framming Berita Di TribunJatim.com

\begin{tabular}{|c|c|c|}
\hline Elemen & Khofifah-Emil & Gus Ipul-Puti \\
\hline Frame & $\begin{array}{l}\text { Pasangan khofifah-emil } \\
\text { mendapatkan legitimasi serta } \\
\text { dukungan dari mayoritas } \\
\text { tokoh masyakat dan Kyai } \\
\text { kampung }\end{array}$ & $\begin{array}{l}\text { Pasangan gus ipul-puti } \\
\text { mendapatkan legitimasi serta } \\
\text { dukungan dari partai politik } \\
\text { dan Lembaga/organisasi } \\
\text { masyarakat }\end{array}$ \\
\hline $\begin{array}{c}\text { Problem identification/ } \\
\text { Define problems }\end{array}$ & $\begin{array}{l}\text { Jawa timur membutuhkan } \\
\text { sosok pemimpin dari } \\
\text { kalangan NU, yang memiliki } \\
\text { sifat mengayomi layaknya } \\
\text { seorang ibu dan mempunyai } \\
\text { konsep pembangunan yang } \\
\text { jelas untuk jawa timur }\end{array}$ & $\begin{array}{l}\text { Jatim membutuhkan Sosok } \\
\text { yang mendukung kegiatan } \\
\text { perekonomian masyarakat } \\
\text { (tidak mencantumkan } \\
\text { identitas ke-NU, penekanan } \\
\text { berita hanya pada kunjungan } \\
\text { ke daerah tertentu }\end{array}$ \\
\hline $\begin{array}{c}\text { Causal interpretation/ } \\
\text { diagnose causes }\end{array}$ & $\begin{array}{l}\text { Khofifah-emil adalah } \\
\text { pasangan yang tepat karena } \\
\text { dianggap mampu } \\
\text { menyelesaikan persoalan } \\
\text { yang ada di jawa timur } \\
\text { (dikuatkan data dari } \\
\text { Lembaga survei) }\end{array}$ & $\begin{array}{l}\text { Berada dibawah bayang- } \\
\text { bayang kesuksesan soekarno, } \\
\text { Jokowi dan Soekarwo }\end{array}$ \\
\hline $\begin{array}{c}\text { Moral evaluation/make } \\
\text { moral judgment }\end{array}$ & $\begin{array}{l}\text { Khofifah-emil adalah } \\
\text { pasangan yang mempunyai } \\
\text { integritas, kredibel, jujur, dan } \\
\text { pandai }\end{array}$ & $\begin{array}{l}\text { Gus ipul - puti adalah sosok } \\
\text { yang sholeh karena } \\
\text { keturunan orang sholeh }\end{array}$ \\
\hline $\begin{array}{l}\text { Treatment } \\
\text { recommendation }\end{array}$ & $\begin{array}{l}\text { Memenuhi syarat untuk } \\
\text { menjadi pemimpin. Karena } \\
\text { terdapat sifat Shidiq, } \\
\text { Amanah, Tabligh, dan } \\
\text { Fathonah }\end{array}$ & $\begin{array}{l}\text { Sebagai sosok yang } \\
\text { mengawal secara langsung } \\
\text { pembangunan di Jawa Timur }\end{array}$ \\
\hline
\end{tabular}

Sumber: Data Analisis Peneliti 
Tabel 2. Analisis Framming Berita Di JPNN.com

\begin{tabular}{|c|c|c|}
\hline Elemen & Khofifah-Emil & Gus Ipul-Puti \\
\hline Frame & $\begin{array}{l}\text { Mendapatkan legitimasi serta } \\
\text { dukungan dari mayoritas } \\
\text { Kyai NU Jawa Timur dan } \\
\text { kelompok organisasi } \\
\text { perempuan }\end{array}$ & $\begin{array}{l}\text { Mendapatkan legitimasi serta } \\
\text { dukungan dari golongan } \\
\text { nasionalis dan Nadiyin } \\
\text { (dikuatkan dengan berita tentang } \\
\text { maklumat pimpinan Pondok } \\
\text { Sidogiri KH Nawawi Abdul } \\
\text { Jalil untuk semua alumni pondok } \\
\text { memilih Gus ipul-puti, serta } \\
\text { berita tentang dukungan dari } \\
\text { Jokowi dan megawati) }\end{array}$ \\
\hline $\begin{array}{c}\text { Problem identification/ } \\
\text { Define problems }\end{array}$ & $\begin{array}{l}\text { Masyarakat jatim } \\
\text { membutuhkan pemimpin } \\
\text { yang amanah }\end{array}$ & $\begin{array}{l}\text { Masyarakat Jatim adalah } \\
\text { masyarakat yang memiliki } \\
\text { keterikatan emosional } \\
\text { dengan bung Karno serta } \\
\text { merupakan basis NU }\end{array}$ \\
\hline $\begin{array}{c}\text { Causal interpretation/ } \\
\text { diagnose causes }\end{array}$ & $\begin{array}{l}\text { Khofifah-Emil adalah } \\
\text { pasangan yang memiliki } \\
\text { gagasan, perencanaan untuk } \\
\text { mewujudkan Jatim lebih baik }\end{array}$ & $\begin{array}{l}\text { Jatim menginginkan } \\
\text { pemimpin rendah hati } \\
\text { dengan karya yang nyata dan } \\
\text { tidak mudah berpindah- } \\
\text { pindah partai demi } \\
\text { kepentingan politik }\end{array}$ \\
\hline $\begin{array}{l}\text { Moral evaluation/make } \\
\text { moral judgment }\end{array}$ & $\begin{array}{l}\text { Khofifah adalah orang yang } \\
\text { amanah, bertaqwa. } \\
\text { Memikirkan kepentingan } \\
\text { umat }\end{array}$ & $\begin{array}{l}\text { Pasangan Gus Ipul-Puti } \\
\text { mempunyai program yang } \\
\text { realistis, konkrit dan tidak } \\
\text { diawang-awang }\end{array}$ \\
\hline Treatment recomendation & $\begin{array}{l}\text { Pasangan khofifah-emil akan } \\
\text { menang karena didukung } \\
\text { oleh mayoritas pendukung } \\
\text { perempuan. } \\
\text { (dikuatkan dengan berita } \\
\text { tentang dukungan } 380 \\
\text { Ulama jatim Muslimat NU } \\
\text { kepada pasangan Khofifah- } \\
\text { Emil serta hasil survei) }\end{array}$ & $\begin{array}{l}\text { Jatim akan tenteram jika } \\
\text { dipimpin oleh pasangan } \\
\text { Nasionalis-Nahdiyin }\end{array}$ \\
\hline
\end{tabular}

Sumber: Data Analisis Peneliti

Pemilihan Gubernur dan wakil gubernur Jawa timur tahun 2018 memang merupakan kontestasi politik yang menarik. Hal ini terkait dengan adanya dua pasang calon yang keduanya merupakan "saudara" seorganisasi masyarakat; Nahdatul Ulama (NU). Khofifah Indar Parawansa merupakan Ketua Umum PP Muslimat Nahdlatul Ulama periode 2000-2005 sedangkan Saifullah Yusuf merupakan Ketua Umum GP Anshor periode 2005-2010. Apalagi ditambah secara wilayah, Jawa Timur 
merupakan basis massa dari NU sehingga bisa dilihat bagaimana pertandingan “derby" menjadi sangat menarik.

Strategi dan kampanye politik dilakukan oleh kedua pasangan dalam rangka memperebutkan massa terutama massa dari kalangan NU. Mulai dari kampaye secara langsung atau melalui media. Dari hasil analisis peneliti diatas dapat dilihat bagaimana bingkai pemberitaan yang dilakukan oleh tribun jatim.com dan jpnn.com. Kedua media tersebut sama-sama melakukan bingkai terhadap kedua pasangan calon dari aspek perolehan dukungan tokoh agama (Kyai). Hal ini sangat lumrah karena restu kiai masih dijadikan sebagai preferensi pilihan masyarakat. Tentu pembingkaian ini tak terlepas dari tipologi atau karakter masyarakat Jawa Timur.

\section{Bagan 1. Tipologi Pemilih}

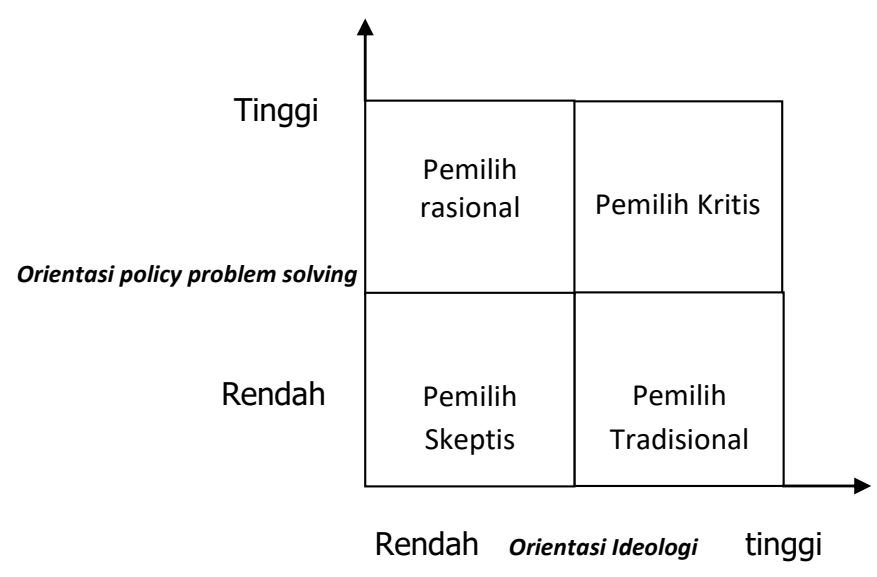

Sumber: Firmansyah; Marketing Politik 2012

Keterangan:

1) Pemilih rasional: pemilih yang memiliki orientasi policy problem solving tinggi

2) Pemilih kritis: pemilih yang memiliki perpaduan orientasi policy problem solving dan orientasi ideologi yang tingggi

3) Pemilih skeptis: pemilih yang tidak memiliki orientasi entah itu orientasi policy problem solving dan orientasi ideologi

4) Pemilih tradisional: pemilih yang memiliki orientasi ideologi tinggi 
Firmansyah dalam buku Marketing politik (2012:119-126) menjelaskan dalam menentukan pilihan politik, seorang pemilih akan ditentukan oleh faktor orientasi yang dominan dalam dirinya. Faktor orientasi tersebut, (1) Orientasi kebijakan penyelesaian masalah (policy problem solving): orientasi pemilih terhadap calon didasarkan pada aspek kognisi. Artinya para pemilih yang berada dalam orientasi ini lebih menekankan pada calon yang mampu memecahkan problem dalam masyarakat. Untuk menarik simpati pemilih ini seorang calon harus mempunyai kemampuan dalam berargumentasi serta menawarkan solusi-solusi yang disertai dengan data-data yang akurat. Hal ini dikarenakan pemilih ini adalah pemilih yang lebih mengedepankan rasionalitas logis mereka. (2) Orientasi ideologi: pada orientasi ini pemilih lebih menekankan aspek kedekatan emosi, subyektivitas dan afektif. Semakin dekat (adanya persamaan) pemilih dengan calon misalnya nilai budaya, agama, moralitas, norma dan emosi maka semakin besar kecenderungan untuk menjadi bagian dari ikatan. Dari kedua orientasi tersebut dapat digambarkan tipologi pemilih berdasarkan pada tinggi dan rendahnya tingkat orientasi yang ada pada diri pemilih melalui bagan 1.

Dari pembingkaian berita oleh JPNN.com dan Tribun Jatim jika dilihat dari karakter pemilih diatas secara jelas menggunakan ketokohan Kyai sebagai cara untuk mendapatkan simpati pemilih. Hal ini sesuai dengan karakter pemilih di Jawa Timur yang secara mayoritas masuk dalam kategori pemilih tradisional. Bagi masyarakat jawa timur, terutama yang berada di wilayah tapal kuda dan Madura yang nota-bene merupakan basis massa NU, sosok Kyai merupakan tokoh sentral pemimpin non formal (cultural religious) yang dianggap memiliki kelebihan secara spiritual, basis massa, dan kedudukan social yang setiap perintah dan anjurannya akan ditaati oleh massanya (santri). Pasangan calon yang mendapatkan restu dari Kyai dianggap merupakan representasi dari Kyai itu sendiri. Sehingga strategi pembingkaian berita di media bahwa para calon mendapatkan dukungan Kyai merupakan hal yang mutlak harus dilakukan.

Selanjutnya untuk wilayah jawa timur diluar wilayah tapal kuda dan madura (biasanya disebut arek dan matraman), framing pemberitaan yang dilakukan adalah pasangan calon mendapatkan dukungan dari organisasi masyarakat serta 
menekankan pada sosok yang mampu menguarai permasalahan di Jawa Timur. Bisa dikatakan tipologi pemilih di wilayah ini adalah pemilih rasional.

Berbeda dengan karakter masyarakat tapal kuda dan Madura yang lebih mempunyai orientasi ideologi jika dilihat dari bagan tipologi pemilih diatas merupakan pemilih tradisional, pada masyarakat matraman ini cenderung berkarakter perkotaan yang orientasi pilihan politiknya lebih mengedepankan policy problem solving. Perencanaan, kebijakan yang ditawarkan, performance saat acara debat publik, data-data akurat disampaikan dalam setiap kampanye merupakan faktor pertimbangan oleh pemilih untuk menentukan siapa calon yang akan dipilih.

Tindakan tersebut diatas merupakan cerminan bahwa pilihan seseorang terhadap calon, merupakan hasil pemaknaan mereka (yang berasal dari media yang mereka baca). Walaupun dengan tingkat terpaan yang berbeda, kampanye politik melalui pemberitaan di media dirasa masih efektif untuk merubah sikap dan perilaku (mempersuasi) para pemberi suara. Ditilik dari tabel diatas terutama pada bagian moral judgement kedua media tersebut memberikan argument bahwa kedua calon gubernur dan wakil gubernur Jawa Timur adalah sosok pilihan yang tepat dengan kredibilitas individu yang mumpuni.

\section{Kesimpulan}

Pemilihan Gubernur dan wakil gubernur jawa timur tahun 2018 memang menarik. Selain karena rivalitas kedua pasangan calon gubernur berasal dari NU dan masyarakat jawa timur merupakan basis massa dari NU, sehingga suasana kompetisi isu agama tidak bisa dimainkan di jawa timur. Hal ini berbeda dengan pemilihan gubernur dan wakil gubernur DKI Jakarta. Strategi kampanye dan pemberitaan di media lebih diarahkan ke program kerja untuk menyelesaikan permasa-lahan yang ada di jawa timur serta klaim mendapatkan dukungan dari tokoh agama dan organisasi masyarakat.

Kondisi masyarakat yang berubah seiring dengan kemajuan teknologi informasi dan komunikasi juga berdampak pada kecenderungan dalam memilih calon pemimpin. Jika dilihat dari karakter pemilih berdasarkan data survey yang dilakukan oleh polltracking tahun 2018, 49.3\% pemilih jawa timur adalah pemilih rasional, $25.1 \%$ adalah pemilih tradisional. Dari jumlah prosentase pemilih rasional tersebut 
sebagian besar berasal dari pemilih milenial sehingga menjadi lahan atau potensi pemilih yang harus diperebutkan.

Hal inilah yang menjadikan pembingkaian berita pemilihan gubernur dan calon wakil gubernur jawa timur tahun 2018, cenderung untuk merebutkan potensi pemilih rasional namun tetap tidak meninggalkan karakter pemilih tradisional yang masih eksis di Jawa Timur. Artinya bingkai pemberitaan yang dilakukan tribunjatim.com dan JPNN.com sama-sama mengkonstruksi pasangan calon khofifah-Emil, Gus Ipul-Puti adalah pasangan yang mendapatkan dukungan dari Kyai (tokoh agama) dan kelompok masyarakat terutama dari NU dan Nasionalis.

\section{Referensi}

Buku:

Eriyanto. (2001). Analisis W acana: Pengantar Analisi Teks Media. Yogyakarta: LKiS.

Eriyanto. (2018). Media dan Opini Publik; Bagaimana Media Menciptakan Isu (agenda setting) Melakukan Pembingkaian (Framming) dan Mengarabkan Pandangan Publik (Priming). Depok: Rajawali Pres

Firmanzah. (2012). Marketing Politik Antara Pemahaman dan Realitas, Jakarta: Buku Obor

Hamad, Ibnu. (2004). Konstruksi Realitas Politik Dalam Media Massa. Jakarta: Granit Heryanto, Gun. (2018). Media Komunikasi Politik; Relasi Kuasa Media di Panggung Politik. Yogyakarta: IRCISoD

Michael Rush \& Philip Althoff. (2007). Pengantar Sosiologi Politik, Jakarta: PT Raja Grafindo Persada,

M, Romli, Asep Syamsul. (2012). Jurnalistik Online: Panduan Praktis Mengelola Media Online; Dilengkapi Kiat Blogger, Teknik SEO, dan Tips Media Sosial. Bandung: Nuansa Cendekia.

Pawito. (2009). Komunikasi Politik. Media Massa dan Kampanye Pemilihan. Yogyakarta: Jalasutra

Rakhmat, Jalaludin. (2007). Metode Penelitian Komnikasi. Bandung: PT Remaja Rosdakarya

Subiakto, Henry dan Rachmah Ida. (2012). Komunikasi Politik, Media Dan Demokrasi. Jakarta: Kencana 
Sudibyo, Agus. (2001). Politik. Media Dan Pertarungan Wacana. Yogyakarta: 1kis

Wasis, Kun. (2012). Media Massa dan Konstruksi Realitas. Yogyakarta: Aditya Media

\section{Jurnal:}

Dwi Anggoro, Ayub. (2014). 'Media, Politik dan Kekuasaan (Analisis Framing Model Robert N. Entman tentang pemberitaan hasil pemilihan Presiden, 9 Juli 2014 di TV One dan Metro TV)', Jurnal Aristo, Vol 2, No 2, hh 25-52, http://journal.umpo.ac.id/index.php/aristo/article/viewFile/16/275 diakses pada 24 Mei 2019 pukul 16:20 WIB

Nugroho, Adi. (2012). Analisis Framing Pemberitaan Pilgub Jateng Pada Harian Suara Merdeka, Jurnal Interaksi, Vol.1 No.1, hh. 1-9. https://ejournal.undip.ac.id/index.php/ilmusos/article/view/10277/81 55 diakses pada 14 Mei 2019 pukul 16:27 WIB

Yuniarti. Tatik \& Kartini Rosmala, (2011). 'Analisis Framing Berita Makelar Kasus Di Institusi Kepolisian Pada Surat Kabar Kompas Dan Republika Edisi 19 23 Maret 2010 (Studi Analisis Framing Model Pan Dan Kosicki)', Jurnal FKSB MAKNA, Vol. 2, No.01, hh. 15-28, http://jurnal.unismabekasi.ac.id/index.php/makna/article/view/762/64 6 diakses pada 16 Mei 2019 pukul 13:18 WIB

Herayani, Ni Wayan., I Wayan Wendra., \& I Dewa Gede Budi Utama, (2016). 'Pemberitaan hubungan jokowi dengan megawati di media kompas.com, republika.co.id, dan tempo.co: analisis framing Robert n. Entman', Jurnal Pendidikan Bahasa dan Sastra, Vol 5, No 3, https://ejournal.undiksha.ac.id/index.php/JJPBS/article/view/8690/56 56. diakses pada 26 Mei 2019 pukul 20:20 WIB

\section{Website}

Adk. (2018, April 03). Puti Disambut Hangat di Pondok Pesantren Tremas Pacitan. JPNN. https://pilkada.jpnn.com/news/puti-disambut-hangat-di-pondokpesantren-tremas-pacitan.

Adk (2018, April 10). Debat Pilgub Jatim, Gus Ipul - Puti Beber Pengembangan Madin. JPNN. https://pilkada.jpnn.com/news/debat-pilgub-jatim-gus-ipul-putibeber-pengembangan-madin. 
Adk. (2018, April 10). Debat Pilgub Jatim: Seru! Emil Agresif, Puti Woles. JPNN. https://www.jpnn.com/news/debat-pilgub-jatim-seru-emil-agresif-putiwoles.

Bae dan Nug. (2018, April 03). Sifat Amanah Ada di Khofifah Indar Parawansa. JPNN. https://pilkada.jpnn.com/news/sifat-amanah-ada-di-khofifah-indarparawansa

Bae. (2018, Juni 04). 380 Ulama Jatim Berkumpul Demi Khofifah - Emil. JPNN. https://pilkada.jpnn.com/news/380-ulama-jatim-berkumpul-demikhofifah-emil

Jp dan Adk. (2018, April 02). AHY Sampai Lempar Rompi Saat Kampanye Khofifah Emil. JPNN. https://pilkada.jpnn.com/news/ahy-sampai-lempar-rompisaat-kampanye-khofifah-emil.

Jpnn. (2018, Mei 16). Survei Pilgub Jatim 2018: Khofifah - Emil Unggul Jauh. JPNN. https://www.jpnn.com/news/survei-pilgub-jatim-2018-khofifah-emilunggul-jauh

Jpnn. (2018, April 10). Pilgub Jatim: Elektabilitas Naik, Dukungan Mengalir. JPNN. https://pilkada.jpnn.com/news/pilgub-jatim-elektabilitas-naikdukungan-mengalir. Diakses pada

Jpnn. (2018, 01 April). Kampanye Akbar Khofifah- Emil, AHY: Jawa Timur Beruntung Punya Calon Pemimpin Berkarakter. TribunJatim. Diakses dari https://jatim.tribunnews.com/2018/04/01/kampanye-akbar-khofifahemil-ahy-jawa-timur-beruntung-punya-calon-pemimpin-berkarakter

Koloway, Bobby Constantine. (2018, 07 April). KAMI Ajak Pemuda Sebat Lewat Program Ini, Cocok dengan Visi Puti Soekarno. TribunJatim. Diakses dari https://jatim.tribunnews.com/2018/04/07/kami-ajak-pemuda-sehatlewat-program-ini-cocok-dengan-visi-puti-soekarno

Koloway, Bobby Constantine. (2018, 05 April). Burub Jatim Kompak Menangkan Gus Ipul- Puti. TribunJatim. Diakses dari https://jatim.tribunnews.com/2018/04/05/buruh-jatim-kompakmenangkan-gus-ipul-puti

Sakti, Sofyan Arif Candra. (2018, 01 April). Dukung Gus Ipul, Pesantren Syaichona Cholil Bangkalan Kalungkan Serban Saat Musyawarah Besar. TribunMadura. 
Diakses dari https://jatim.tribunnews.com/2018/04/01/dukung-gusipul-pesantren-syaichona-cholil-bangkalan-kalungkan-serban-saatmusyawarah-besar

Sakti, Sofyan Arif Candra. (2018, 01 April). Di Sumenep, Gus Ipul- Mbak Puti Didukung Relawan yang Sudah Terbentuk sejak, 5 Tahun Lalu. TribunJombang. Diakses dari https://jatim.tribunnews.com/2018/04/01/di-sumenep-gus-ipulmbak-puti-didukung-relawan-yang-sudah-terbentuk-sejak-5-tahun-lalu Sakti, Sofyan Arif Candra. (2018, 01 April). Dipimpin Para Kiai Sepub, Ribuan Relawan Berikrar Dukung Gus ipul Mbak Puti. TribunJatim. Diakses dari https://jatim.tribunnews.com/2018/04/01/dipimpin-para-kiai-sepuhribuan-relawan-berikrar-dukung-gus-ipul-mbak-puti

Sakti, Sofyan Arif Candra. (2018, 03 April). Berkunjung ke Ponpes Tremas Pacitan, Kiai Fuad Doakan Mbak Puti dan Jokowi Sukses di Pemilu. TribunJatim. Diakses dari https://jatim.tribunnews.com/2018/04/03/berkunjung-ke-ponpestremas-pacitan-kiai-fuad-doakan-mbak-puti-dan-jokowi-sukses-di-pemilu

Sakti, Sofyan Arif Candra. (2018, 05 April). Dianggap sebagai Sababat Seniman Jawa Timur, Kirun Berikan Dukungan pada Gus Ipul. TribunMadiun.Diakses dari https://jatim.tribunnews.com/2018/04/05/dianggap-sebagai-sahabatseniman-jawa-timur-kirun-berikan-dukungan-pada-gus-ipul

Sakti, Sofyan Arif Candra. (2018, 05 April). Didukung Fatayat Magetan, Mbak Puti Jelaskan Program Prioritas untuk Perempuan. TribunJatim. Diakses dari https://jatim.tribunnews.com/2018/04/05/didukung-fatayat-magetanmbak-puti-jelaskan-program-prioritas-untuk-perempuan

Sakti, Sofyan Arif Candra. (2018, 05 April). Ribuan Karyawan Pabrik Rokok di Madiun Dukung Gus Ipul di Pilgub Jatim. TribunJatim. Diakses dari https://jatim.tribunnews.com/2018/04/05/ribuan-karyawan-pabrikrokok-di-madiun-dukung-gus-ipul-di-pilgub-jatim

Sakti, Sofyan Arif Candra. (2018, 04 April). PDIP Ponorogo Siap Berikan kado 70 Persen Kemenangan untuk Ulang Tabun Mbak Puti. TribunJatim. Diakses dari https://jatim.tribunnews.com/2018/04/04/pdip-ponorogo-siapberikan-kado-70-persen-kemenangan-untuk-ulang-tahun-mbak-puti 
Sakti, Sofyan Arif Candra. (2018, 04 April). Silarurahmi ke Aisyiyah Ponorogo, Puti Guntur Soekarno: Programnya Sejalan dengan Kami. TribunJatim. Diakses dari https://jatim.tribunnews.com/2018/04/04/silaturahmi-ke-aisyiyahponorogo-puti-guntur-soekarno-programnya-sejalan-dengan-kami Sakti, Sofyan Arif Candra. (2018, 07 April). Kiai Idris Hamid Sebut Hanya Gus Ipul yang Bisa Melanjutkan Kesuksesan KarSa Pimpin jawa Timur. TribunJatim. Diakses dari https://jatim.tribunnews.com/2018/04/07/kiai-idris-hamid-sebuthanya-gus-ipul-yang-bisa-melanjutkan-kesuksesan-karsa-pimpin-jawatimur

Sakti, Sofyan Arif Candra. (2018, 06 April). Bertemu dengan Kiai Idris Hamid dan Habib Taufiq Assegaf di Pasuruan, Gus Ipul Dapat Pesan Khusus. TribunPasuruan. Diakses dari https://jatim.tribunnews.com/2018/04/06/bertemudengan-kiai-idris-hamid-dan-habib-taufiq-assegaf-di-pasuruan-gus-ipuldapat-pesan-khusus

Sakti, Sofyan Arif Candra. (2018, 06 April). Tsamara Amany: Ternyata PSI Sama degan Gus Ipul- Mbak Puti. TribunJatim. Diakses dari https://jatim.tribunnews.com/2018/04/06/tsamara-amany-ternyata-psisama-dengan-gus-ipul-mbak-puti

Sakti, Sofyan Arif Candra. (2018, 08 April). Usung 'Kembang Sari', Gus Ipul-Mbak Puti Dapat Dukungan Penyandang Disabilitas Kabupaten Blitar. TribunJatim. Diakses dari https://jatim.tribunnews.com/2018/04/08/usungkembang-sari-gus-ipul-mbak-puti-dapat-dukungan-penyandangdisabilitas-kabupaten-blitar

Sakti, Sofyan Arif Candra. (2018, 09 April). Ini Alasan Ulama dan Pengasub Pesantren seLumajang dan Jember Deklarasi Dukung Gus Ipul- Mbak. Puti. TribunJatim. Diakses dari https://jatim.tribunnews.com/2018/04/09/ini-alasanulama-dan-pengasuh-pesantren-se-lumajang-dan-jember-deklarasidukung-gus-ipul-mbak-puti

Sakti, Sofyan Arif Candra. (2018, 10 April). Rindu Kerja Sama Nasionalis- Religius, kanang Optimis Gus Ipul- Mbak Puti Bisa Unggul di Mataraman. TribunJatim. Diakses dari https://jatim.tribunnews.com/2018/04/10/rindu-kerja- 
sama-nasionalis-religius-kanang-optimis-gus-ipul-mbak-puti-bisa-ungguldi-mataraman

Toriq, Aqwamit. (2018, 02 April). Sudah Kenal Khofifah Puluban Tabun, Rhoma Irama Yakin Khofifah Punya Sifat dari Pemimpin Islam. TribunJatim. Diakses dari https://jatim.tribunnews.com/2018/04/02/sudah-kenal-khofifahpuluhan-tahun-rhoma-irama-yakin-khofifah-punya-sifat-dari-pemimpinislam

Toriq, Aqwamit. 2018, 01 April). Rhoma Irama Hadiri Kampanye Akbar Khofifah-Emil di Jombang, Raja Dangdut KW Jadi Sasaran Foto Warga. TribunJatim. Diakses dari https://jatim.tribunnews.com/2018/04/01/rhoma-irama-hadirikampanye-akbar-khofifah-emil-di-jombang-raja-dangdut-kw-jadi-sasaranfoto-warga

Toriq, Aqwamit. (2018, 03 April). Elektabilitas Khofifah- Emil Terus Naik, Peneliti: Mereka Representasi Lintas Generasi. TribunJatim. Diakses dari https://jatim.tribunnews.com/2018/04/03/elektabilitas-khofifah-emilterus-naik-peneliti-mereka-representasi-lintas-generasi

Toriq, Aqwamit. (2018, 05 April)). Langkah Khofifah Emil Makin Lancar di Pilgub Jatim 2018 Berkat Dukungan Ulama dan Kiai di Jember. TribunJember. Diakses dari https://jatim.tribunnews.com/2018/04/05/langkah-khofifah-emilmakin-lancar-di-pilgub-jatim-2018-berkat-dukungan-ulama-dan-kiai-dijember

Toriq, Aqwamit. (2018, 05 April). Banser Banyuwangi Nyatakan Dukungan untuk Khofifah- Emil. TribunJatim. Diakses dari https://jatim.tribunnews.com/2018/04/05/banser-banyuwanginyatakan-dukungan-untuk-khofifah-emil

Zahroh, Fatimatuz. (2018, 01 April). Awali Turba ke 17 Kabupaten/Kota di Jatim, AHY Sarapan Bareng Khofifah- Emil di Rumah Pendiri NU. TribunJombang. Diakses dari https://jatim.tribunnews.com/2018/04/01/awali-turba-ke17-kabupatenkota-di-jatim-ahy-sarapan-bareng-khofifah-emil-di-rumahpendiri-nu

Zahroh, Fatimatuz. (2018, 01 April). Kampanye Pilgub Jatim, SBY Orasi Ajak Masyarakat Pilih Budhe Khofifah. TribunJombang. Diakses dari 
https://jatim.tribunnews.com/2018/04/01/kampanye-pilgub-jatim-sbyorasi-ajak-masyarakat-pilih-budhe-khofifah

Zahroh, Fatimatuz. (2018, 04 April). Korban Lumpur Lapindo Doakan Khofifah Jadi Gubernur. TribunBanyuwangi. Diakses dari https://jatim.tribunnews.com/2018/04/04/korban-lumpur-lapindodoakan-khofifah-jadi-gubernur

Zahroh, Fatimatuz. (2018, 07 April). Solid Mendukung, Muslimat Mojokerto Sebut Khofifah Mampu Menata Umat. TribunJatim. Diakses dari https://jatim.tribunnews.com/2018/04/07/solid-mendukung-muslimatmojokerto-sebut-khofifah-mampu-menata-umat

Zahroh, Fatimatuz. (2018, 08 April). Kiai Ali Gondrong dan Ribuan Mafia Salawat di Ngawai Siap Menangkan Khofifah. TribunMadiun. Diakses dari https://jatim.tribunnews.com/2018/04/08/kiai-ali-gondrong-danribuan-mafia-salawat-di-ngawai-siap-menangkan-khofifah

Zahroh, Fatimatuz. (2018, 08 April). Pengasub Ponpes Suryalaya Sebut Cukup Satu Alasan Pilib Dukung Cagub Khofifah. TribunJatim. Diakses dari https://jatim.tribunnews.com/2018/04/08/pengasuh-ponpes-suryalayasebut-cukup-satu-alasan-pilih-dukung-cagub-khofifah 